\title{
JOURNAL
}

of Health Inequalities

\section{Report from the Conference on Smoke-free Poland, Ministry of Health, Warsaw, Poland, 18 May 2016}

\author{
Mateusz Zatoński \\ London School of Hygiene and Tropical Medicine, London, UK \\ Health Promotion Foundation, Nadarzyn, Poland
}

ADDRESS FOR CORRESPONDENCE: Mateusz Zatoński, London School of Hygiene and Tropical Medicine, Keppel Street, London WC1E 7HT, UK, e-mail: mateusz.zatonski@lshtm.ac.uk

The conference, organised by the Ministry of Health of Poland in collaboration with the Health Promotion Foundation (Fundacja "Promocja Zdrowia"), was attended by over 100 participants representing a wide variety of backgrounds - physicians, politicians, civil servants, artists, journalists, and many others. This breadth was characteristic of the diverse nature of the anti-tobacco movement in Poland. It was this extensive coalition that helped to bring the Polish Anti-Tobacco Law to be accepted by the Polish Parliament in 1995 and enacted in May 1996 [1]. The range of expertise was reflected in the list of awardees of the Polish Ministerial and State Merit Awards for Outstanding Contributions to Healthcare (see the Box 1). The award ceremony, presided by Dr Konstanty Radziwiłł, the Minister of Health of Poland, opened the Conference on Smokefree Poland (Fig. 1).

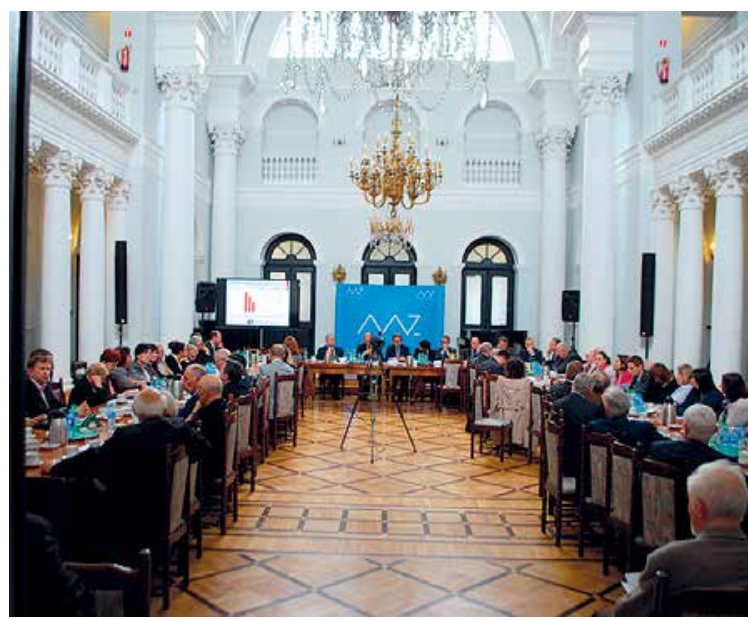

FIG. 1. Participants of the Conference on Smoke-free Poland in the Column Hall of the Ministry of Health

\section{WELCOME ADDRESS BY DR KONSTANTY} RADZIWI $Ł$, MINISTER OF HEALTH OF POLAND

In his welcome address, Konstanty Radziwiłł (Fig. 2) reminded the participants that thirty years ago Poland was one of the global leaders in smoking prevalence. He pointed out that it was the people gathered in the Ministry of Health, 'an incredible group of veterans of tobacco control in Poland, who were the first to understand what a grave impact these smoking rates would have on the health of Poles. He also attributed the success of the anti-tobacco efforts in Poland in the last decades to their efforts.

Minister Radziwiłł called the Polish Anti-Tobacco Law of 1995 a crucial milestone in Poland's road to limiting smoking. He praised its educational role in building awareness of smoking harm, both among the public and among health professionals. It was through discussions

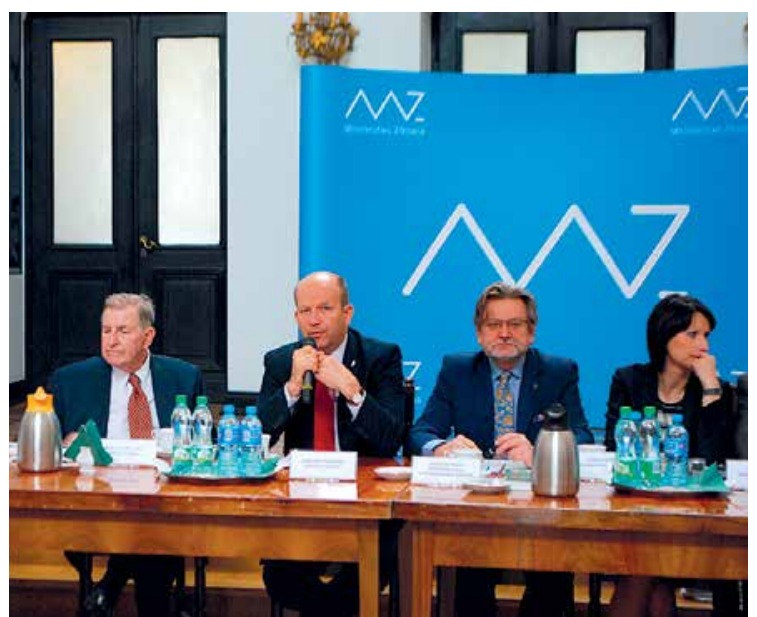

FIG. 2. Dr Konstanty Radziwiłł 
BOX 1. List of recipients of the Polish Ministerial and State Merit Awards for Outstanding Contributions to Healthcare

\section{Urszula Blicharz}

Pedagogue, Director of the Board of Education in Tarnów. One of the initiators and implementers of the programme involving schools in the promotion of recommendations of the European Code Against Cancer in Poland. The programme has been assessed by the European Cancer League as the best implementation of the code in Europe.

\section{Krzysztof Czabański}

Journalist and Publicist. In the years 2015-2016, Secretary of State at the Ministry of Culture and National Heritage; from 2016, president of the National Media Council. Co-organise of the first Great Polish Smoke-out competition and social campaign. In the 1980s a collaborator of the Polish Anti-Tobacco Society.

\section{Urszula Dudziak}

Psychologist, theologian. Professor at the Catholic University of Lublin. Initiator of the involvement of Catholic organisations in social actions aimed at reducing smoking. Co-founder of prevention programmes for young mothers and against smoking in pregnancy.

\section{Zofia Dzik}

Long-time Administrative Director of the Health Promotion Foundation. Since the early 1990s, a key organiser of the Great Polish Smoke-out and many other health programmes and research projects coordinated by the Foundation.

\section{Krzysztof Gottesman}

Journalist, publicist, and sociologist. The author of many scientific and press articles related to smoking. Co-organiser of the Great Polish Smoke-out. In the 1980s an associate of the Polish Anti-Tobacco Society and scientist at the Department of Epidemiology in the Cancer Centre and Institute of Oncology in Warsaw. Co-author of the first English-language study on the epidemiology of malignant tumors in Poland.

\section{Jolanta Jabłońska}

Sociologist. Associate of the Department of Epidemiology and Cancer Prevention in the Cancer Centre and Institute of Oncology in Warsaw, co-executor of the government programme to reduce tobacco smoking and of the programme for primary prevention of cancer, co-author of many anti-tobacco scientific and educational materials.

\section{Kinga Janik-Koncewicz}

Project Director at the Health Promotion Foundation, a nutritionist engaged in cancer primary prevention activities, tobacco control coordinator. In the years 2001-2016, a senior researcher at the Department of Epidemiology at the Cancer Center and Institute of Oncology in Warsaw. Involved in health-related projects and intervention programmes conducted in Poland in collaboration with European and international institutions.

\section{Romuald Jaworsk}

Theologian and ethicist, Professor at the Cardinal Stefan Wyszyński University in Warsaw. Co-founder and former president of the Civic Coalition "Tobacco or Health". Advocate of involving Christian ministers and psychologists in efforts to reduce smoking. Initiator of the development of a catechism on health and ethical consequences of smoking.

\section{Piotr Kler}

Entrepreneur and charity activist. One of the first Polish employers to introduce health promotion programmes for employees. Actively supported the public campaign to ban smoking in workplaces, as well as the Great Polish Smoke-out.

\section{Leszek Kołodziejski}

Physician, professor of surgical oncology. Co-ordinator of the school programme for prevention of cancer in Małopolskie voivodeship, which was the most effective large-scale initiative to implement the European Code Against Cancer in Poland. The programme has been assessed by the European Cancer League as the best implementation of the Code in Europe.

\section{Dorota Lewandowska}

Internist, one of the pioneers in the treatment of tobacco dependence in Poland. In cooperation with the Health Promotion Foundation, and the Cancer Centre and Institute of Oncology in Warsaw, she has organised numerous certified trainings in smoking cessation for physicians and nurses.

\section{Maria Przewoźniak}

Engineer of food technology. A long-time employee of the Department of Epidemiology and Cancer Prevention at the Cancer Centre and Institute of Oncology in Warsaw. Since the early 1980s, a co-organiser of many studies and programs for primary prevention of cancer, including the Great Polish Smoke-out.

\section{Iwona Schymalla}

Journalist. A leading advocate of health promotion efforts in the media. One of the key supporters of the Great Polish Smoke-out campaign.

\section{Joanna Szwechowicz}

A long-time employee of the Department of Epidemiology and Cancer Prevention at the Cancer Centre and Institute of Oncology in Warsaw. She participated in the organisation of health programmes associated with tobacco control, conducted by the Health Promotion Foundation and Cancer Centre.

\section{Wojciech Tarkowski}

Mathematician, a long-time employee of the Department of Epidemiology and Cancer Prevention at the Cancer Centre and Institute of Oncology in Warsaw. The co-organiser of the first studies on smoking in Poland. The creator of epidemiological databases on the risk factors for cancer. Co-author of atlases on cancer mortality in Poland and Eastern and Central Europe.

\section{Dorota Zięba}

A long-time employee of the Department of Epidemiology and Cancer Prevention at the Cancer Centre and Institute of Oncology in Warsaw. Associate of the Health Promotion Foundation. Since the early 1990s, participated in organizing numerous health programmes for the prevention of cancers and tobacco control, including the Great Polish Smoke-out. 
surrounding the bill and its implementation that many people understood the full implications smoking had on the health of Poles. Minister Radziwiłł also praised the hard-fought amendment to the Law that was introduced in 2010, and that implemented a ban on smoking in many public places, workplaces, and restaurants. Despite the doom mongering of the amendment's opponents, the ban did not negatively affect the gastronomic industry, and now remains emphasised very positively by the public.

The Minister emphasized that the medical profession must finally accept that smoking is a medical condition, not just a custom or a matter of strong will, and that it must be approached with adequate diagnostics and treatment. He also underlined the importance of programmes striving to protect youth from tobacco addiction. Finally, he highlighted the impact of mass social campaigns co-organised by the Health Promotion Foundation, such as the World No Tobacco Day ("Dzień bez Papierosa") and the Great Polish Smoke-out ("Rzuć Palenie Razem z Nami"). They attracted millions of participants and had a major role in the shaping of attitudes towards smoking in Poland [2].

Dr Konstanty Radziwiłł also spoke about the future of tobacco control in Poland. He keenly embraced the European Union's Tobacco Products Directive (EU TPD) [3], but added that the amendment to the Polish AntiTobacco Law proposed by the Ministry of Health will make the legislation even more comprehensive and regulate more strictly the new generation of products, such as e-cigarettes [4]. These products, despite potentially being less toxic then conventional cigarettes, remain harmful, highly addictive, and could serve as a gateway to smoking for children. The Minister added that without convincing research proving that they are a useful quitting aid, such products cannot be regulated less strictly than combustible tobacco.

\section{LECTURE BY PROFESSOR WITOLD ZATOŃSKI: DEMOCRACY IS HEALTHIER - THE IMPACT OF THE ANTI-TOBACCO LAW ON THE HEALTH OF POLES}

During his lecture, Witold Zatoński recapped the recent history of smoking in Poland - the country's record smoking rates in the 1970s and 1980s, the rapid decline in smoking in the 1990s, and the resulting reversal of the country's catastrophic health trends. These changes were described in-depth in the previous issue of the Journal of Health Inequalities $[5,6]$.

Professor Zatoński spoke of the development of the Polish Anti-Tobacco Law in the 1990s. The call for a legislative solution was a response to the disastrous health situation in which the country found itself at the time. At the peak of the smoking epidemic, in the mid1980 s, as many as $80 \%$ of the men and $50 \%$ of the young adult women were smokers. After the collapse of communism, in the early 1990s, the tobacco industry was one of the first to be privatised in the newly capitalistic country. Transnational tobacco companies hoped for a big commercial success in Poland and a further growth in smoking, as in other post-communist states such as Russia. However, this was not the case in Poland, where smoking rates declined by $10 \%$ between 1990 and 2000 . R.J. Reynolds, which opened a new state-of-the-art tobacco manufacturing plant outside Warsaw in the early 1990s, had to close it just a few years later. The Polish society, asked whether it wants to buy more cigarettes, answered with a resounding 'no!'.

The Polish Anti-Tobacco Law was the first piece of legislation tackling chronic diseases in Poland. The bill was supported by the majority of Polish parliamentarians, and in the last phases of the legislative process it was guided through the Parliament by the left-wing member of parliament Seweryn Jurgielaniec (Fig. 3). The Law led to a total decline of $60 \%$ in the sale of cigarettes in the 1990s and in the beginning of the $21^{\text {st }}$ century. Today, the smoking rates in Poland stand around $28 \%$ in men and $16 \%$ in women. Professor Zatoński contrasted this with the rates of $40 \%$ in Greece, $35 \%$ in Croatia, or $43 \%$ in Russia. The decline in smoking was accompanied by a fantastic improvement in population health. Lung cancer mortality rates dropped rapidly, especially in contrast to other countries of the region, such as Hungary, where smoking was not tackled effectively in the 1990s (Fig. 4).

According to Professor Zatoński, one of the greatest achievements of tobacco control in 1990s Poland was the introduction of the world's largest health warnings on cigarette packs. The straightforward warnings became an effective tool for building the health competences of the population and helped many Poles to understand that smoking leads to cancer and myocardial infarction. The success and progressive nature of the new legislation meant that it became an example to other countries. Most notably, it pushed the EU to follow suit with similar measures.

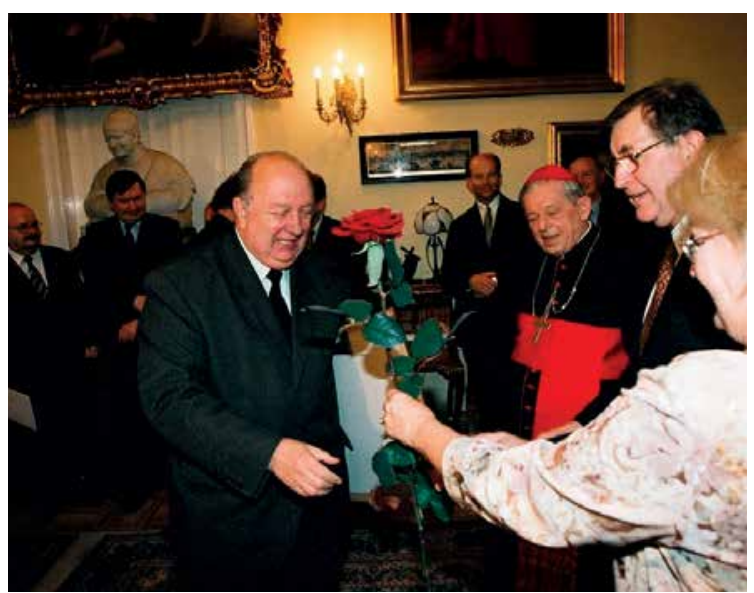

FIG. 3. Dr Seweryn Jurgielaniec, the leader of the political effort to pass the Polish Anti-Tobacco Law 


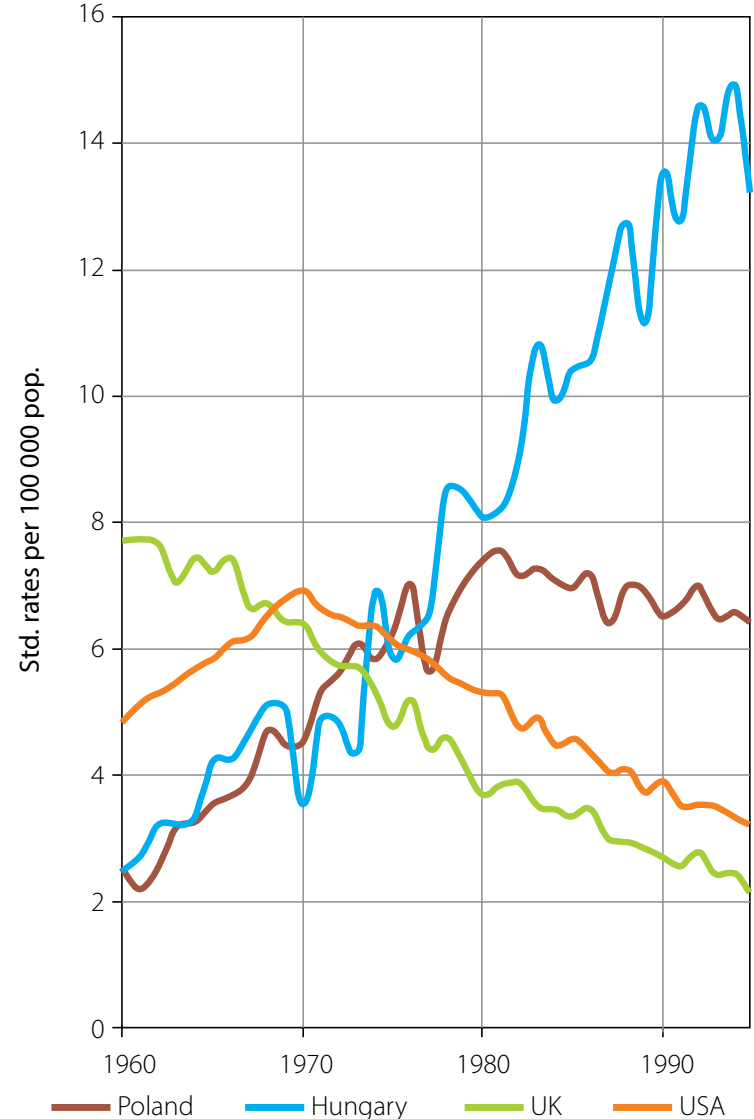

FIG. 4. Lung cancer mortality in Poland, Hungary, UK, and USA; men aged 20-44 years, 1960-1995

Another important aspect of the anti-tobacco legislation introduced in Poland in the 1990s was the complete ban on tobacco advertising. Due to the fierce opposition of the tobacco lobby, the ban was not in the original ver-

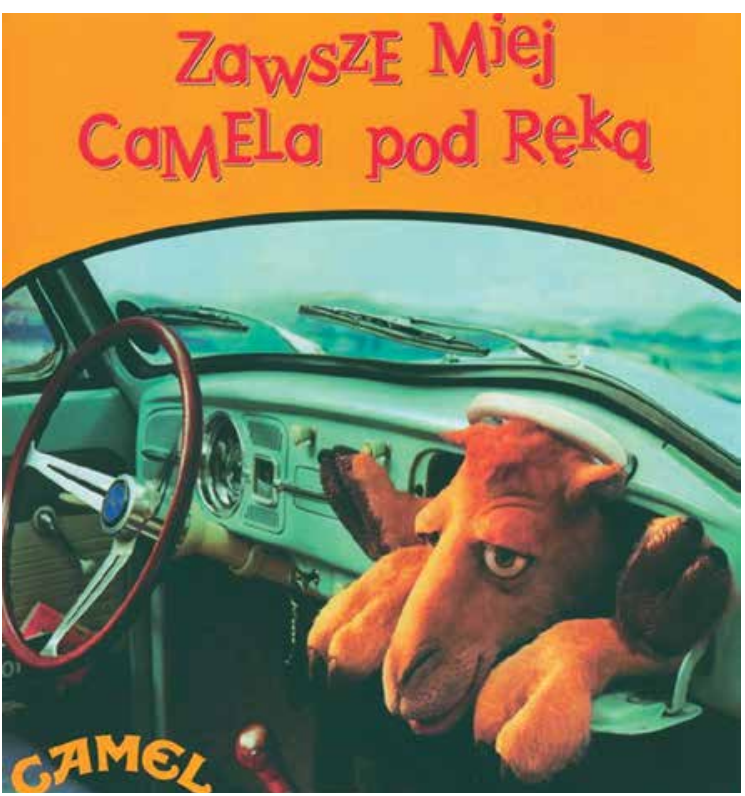

FIG. 5. Example of cigarette advertisement directed to children - "Always have a Camel at your fingertips" sion of the Anti-Tobacco Law of 1995, but was added in its amendment in 1999. In the tumultuous public discussion that accompanied the legislative process, the tobacco industry claimed that the amendment will lead to the collapse of the advertising industry, and that smokers will be left without information on which tobacco product to choose. Thanks to the continuing pressure of the anti-tobacco advocates, an increasingly health-conscious public recognised that cigarette advertisements mainly target children and teenagers. Thanks to the efforts of parliamentarians such as the former Minister of Health Andrzej Wojtyła, the Parliament rejected the arguments of the tobacco industry, and Poland introduced one of the first complete cigarette advertising bans in the world (Fig. 5).

Professor Zatoński went on to list some of the other significant elements of the Polish Anti-Tobacco Law. These included free treatment of tobacco dependence, a tobacco control fund consisting of $0.5 \%$ of the excise tax on tobacco, and a ban on the sponsorship of political parties, politicians, and social organisations by the tobacco industry. Despite the claims of its opponents, the Law proved to be much more than a useless piece of paper. In addition, it is periodically broadened to embrace new public health evidence on what a comprehensive anti-tobacco legislation should include. In 2010, this was the partial ban on smoking in public places. This year, the Anti-Tobacco Law will be harmonised with the EU TPD.

Professor Zatoński also thanked some of the individuals and organisations involved in Poland's tobacco control efforts. These included the Catholic Church and His Eminence Józef Glemp, the Primate of Poland, who took honorary patronage over the Health Promotion Foundation and its flagship action, the Great Polish Smoke-out. The participation of the Catholic Church, one of Poland's leading institutions, gave the anti-tobacco movement greater stability. It also allowed to involve the enormously popular Pope John Paul II into the anti-tobacco efforts. Every year, the Pope granted a private audience to a group of ex-smokers who participated in the annual Great Polish Smoke-out competition, hugely contributing to the great success of this initiative.

Strong support also came from the world of Polish media and culture. The first firm supporter of the health promotion actions was the daily Express Wieczorny, headed by its editor-in-chief Krzysztof Czabański. Another tireless health advocate was the journalist, and later senator, Krystyna Bochenek. Iwona Schymalla, who accompanied groups of ex-smokers visiting the Pope, along with Anna Popek, were two of the journalists involved with the anti-tobacco movement from its early years. Finally, Tadeusz Różewicz, Agnieszka Osiecka, and Andrzej Pągowski were representatives of the world of high culture who always stood behind the efforts aiming at improving the health of Poles.

The medical community was another key element of Poland's anti-tobacco coalition. Jerzy Woy-Wojciechowski, 
who led the Polish Medical Association, and Konstanty Radziwiłł, the head of the Polish Medical Chamber, were two of the staunchest supporters of anti-tobacco measures, as was Jarosław Pinkas, one of the leaders of the Polish general practitioners' community.

Social advocates and politicians also had a crucial impact on the success of Poland's tobacco control efforts. These included the free trade union activist Alina Pieńkowska, senator Janina Fetlińska, the First Lady Jolanta Kwaśniewska, and parliamentarians such as Janusz Szymborski, minister Bolesław Piecha, one of the main original authors of the ban on smoking in public places, or the Minister of Finance Leszek Balcerowicz, who significantly increased the prices of cigarettes. Finally, came the anti-communist dissidents, Krzysztof Czabański, Krzysztof Gottesman, and Zbigniew Mentzel, who already in the communist years worked in the field of public health, and continued to be its firm supporters after the collapse of the authoritarian system.

Finally, Professor Zatoński (Fig. 6) thanked his team and close collaborators, without whom his work towards a healthier Poland would be impossible.

The lecture concluded with a summary of the public health challenges still ahead. The previous 25-years were a time of rapid health improvement, but Poland still remains at the beginning of its path. As many as 8 million Poles are smokers and tens of thousands of Poles die every year of tobacco-related diseases, half of them young or middle-aged. Reducing the number of smokers should remain the priority of public health in Poland, and there are good reasons to believe that the number could be halved to 4 million in 2025-2030. Such a decrease would help to halve premature tobacco-related mortality, strengthen the human capital of the country, and improve its demographic prospects.

New issues, such as the advent of the e-cigarette, should not be ignored, but neither should they take the attention off the main killer in Poland - the conventional combustible cigarette. At the same time, we should acknowledge that nicotine is cardiotoxic and heavily addictive, and the usefulness of e-cigarettes in quitting smoking is far from certain. Much safer, non-addictive products are available on the Polish market. An example is cytisine, which is used by almost a million smokers in Poland every year as a cessation aid, and does not pose the threat of becoming a gateway to smoking for children. It is fortunate that the new EU TPD, supported by the actions of the Ministry of Health, is striving to strictly regulate the new potentially dangerous products.

Tobacco addiction is a curable disease, and it should be treated as such. Over $80 \%$ of smokers want to quit; therefore, one of primary goals of the medical and pharmaceutical community in Poland, especially the Polish Medical Chamber, must be to help them. Finally, the Polish government needs to be an active participant in the anti-tobacco efforts, and this should be reflected in the National

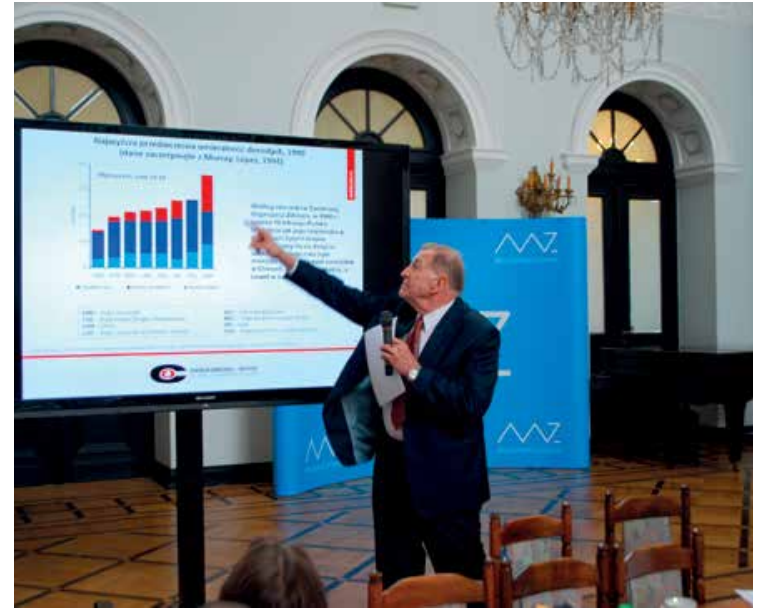

FIG. 6. Professor Witold Zatoński

Public Health Programme, the National Cancer Control Programme, as well as cardiological, neurological, and pneumological plans. Without this, it will be impossible to achieve a desirable reduction in smoking-related diseases in Poland. Witold Zatoński embrace Minister Radziwiłł's declaration that he wants Poland to return to the group of countries at the forefront of tobacco control efforts in Europe. This should be the task for both the experienced and the young public health advocates in Poland.

\section{LECTURE BY MINISTER JAROSŁAW PINKAS: TOBACCO-FREE POLAND}

The Secretary of State in the Ministry of Health, Dr Jarosław Pinkas (Fig. 7), assured the conference participants that the current Ministry of Health is very orthodox when it comes to questions of tobacco harm, and that Poland's anti-tobacco legislation will surpass the provisions in the EU TPD, especially in regards to the regulation of e-cigarettes. In the view of the Ministry there is no other product on which evidence of harm is mounting as quickly, and therefore appropriate regulation is needed.

The Minister pointed out that the success in the fight against tobacco in Poland in the previous decades

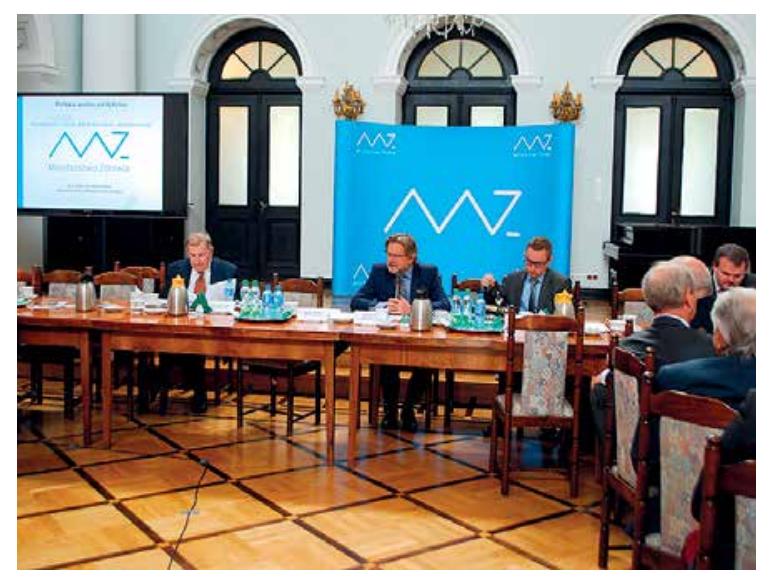

FIG. 7. Dr Jarosław Pinkas 
was mostly down to a small group of determined health advocates who managed to counter one of Poland's greatest health challenges. Nonetheless, despite the progress, data on smoking in Poland remain staggering. As much as $38 \%$ of all deaths in males aged $38-69$ are a result of smoking. This also carries an economic cost, as the Polish taxpayer contributes billions of złoty (PLN) to treating tobacco-related diseases. Minister Pinkas vowed decisive steps to bring these numbers down - drastic health warnings on cigarette packaging, limiting access to flavored cigarettes and menthol, and eventually plain packaging. He also underlined that e-cigarettes will not be treated as a 'lesser evil', but rather as a potential gateway to smoking for young people - there will be a ban on sale of e-cigarettes to anyone under 18-years of age and a ban on vaping in public places. One of the principal goals of the National Public Health Programme will be a focus on anti-tobacco efforts, and funds will be made available for educational efforts raising awareness of smoking and vaping harm.

In concluding his lecture, minister Pinkas announced that together with Professor Zatonski they will prepare a manifesto regarding the tobacco endgame in Europe. He also expressed his hope that if a similar conference is organised in twenty years, one of the most spectacular successes that Minister Radziwiłł will be remembered for will be his struggle against smoking. Minister Pinkas also called on the participants of the conference to support the Ministry of Health in these efforts.

\section{STATEMENT BY PROFESSOR LEIF AAR $\varnothing$}

Professor Aarø (Fig. 8) spoke about his engagement in supporting anti-tobacco efforts in Poland, as well as the collaboration between Norway and Poland in the field of public health. Professor Aarø first started working with the Polish Ministry of Health in 1983. He was involved in the establishment of the World Health Organization survey on Health Behavior in School-Aged Children (HBSC),

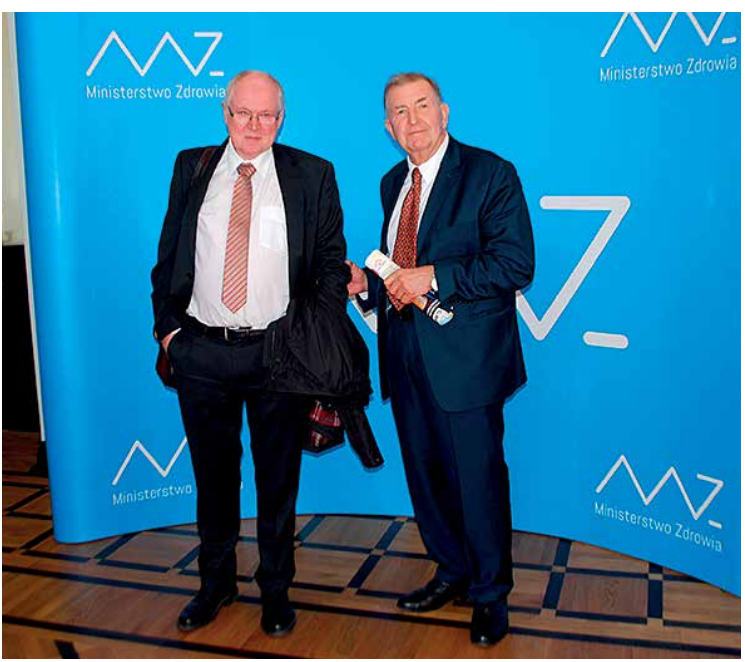

FIG. 8. Professor Leif Aarø in which Poland was one of the early participants. The HBSC survey provided useful statistics about smoking habits among school students, and continues to document the decline in smoking that is taking place, also in Poland.

The collaboration between Norway and Poland intensified after the Polish visit of the Norwegian Minister of Health, Dagfinn Høybråten, in the late 1990s. This resulted in launching of the Polish-Norwegian partnership programme "Smoking prevention and cessation" in the years 2002-2005, conducted by the Norwegian Directorate of Health and Social Affairs in collaboration with the Warsaw Oncology Institute and the Health Promotion Foundation. The results of this collaboration included, amongst others, the development of a strategy for preventing smoking initiation and the treatment of tobacco dependence for the Polish Ministry of Health, the establishment of a modern quit-line in Poland, and the creation of an educational programme for teachers, school nurses, and parents on the protection of children from tobacco smoke. Another collaborative project was the Polish-Norwegian Study, in which Professor Zatoński and his colleagues collaborated closely with the University of Trondheim (NTNU) on a research focused on chronic diseases. At present, there is a close partnership between the Norwegian Directorate of Health and the Polish Ministry of Health within the framework of the EEA grants.

\section{STATEMENT BY KRZYSZTOF GOTTESMAN}

The speaker recalled his involvement in public health efforts in the mid-1980s. At that time, Krzysztof Gottesman was a young journalist connected with the Solidarity trade union and unable to find employment in the stormy political reality of the time. He followed the footsteps of other anti-communist dissidents, Krzysztof Czabański and Zbigniew Mencel, who also found employment in Professor Zatoński's team. At the time, anti-tobacco advocacy was seen as an eccentric and not very serious preoccupation. It was during his work with Professor Zatoński, firstly in the Polish Anti-tobacco Society, and then in the Warsaw Oncology Institute, that Gottesman understood how wrong this perception was. Among others, Gottesman was involved in the preparation and publishing of the first Polish cancer mortality atlas [7].

Krzysztof Gottesman also brought up a few anecdotes that characterised the practice of anti-tobacco advocacy at that time. One of these was the case of Andrzej Strejlau, an ardent smoker who at the end of the 1980s became the coach of the Polish national football team. Professor Zatoński was furious to see that this sports icon, the role-model of thousands of young people, constantly appeared in public with a cigarette. Krzysztof Gottesman drafted a scolding letter to Strejlau. The result was two-fold: Andrzej Strejlau stopped appearing with a cigarette in public, and the story of the letter was picked up by the media, creating an educational opportunity for the anti-tobacco advocates. 


\section{STATEMENT BY PIOTR KLER}

Piotr Kler presented the perspective of a successful businessman and entrepreneur who became involved with health promotion efforts. He remembered that already in 1990, when he was launching his shoe production business, smoking was posing major problems. Among his employees, around $70-80 \%$ were smokers, and cigarettes were omnipresent. In order to tackle this problem, he introduced a system of awarding $6 \%$ bonuses to non-smoking employees. In the month following its introduction, $50 \%$ of the employees promptly quit, and the downward trend continued in the next months. Another method implemented by Piotr Kler to encourage his employees to stop smoking were glass smoking cabins, through which everyone can see the smoker, and which act as an efficient deterrent. Today, out of seventy of his administrative employees, there are only a handful of smokers. Even in the production hall and the sewing room, the smoking rates are down to $10-15 \%$.

\section{STATEMENT BY PROFESSOR TOMASZ ZDROJEWSKI}

Professor Zdrojewski (Fig. 9) opined that Polish medicine has two icons - Professor Zbigniew Religa in curative medicine, and Professor Witold Zatoński in preventive medicine. Without the latter and the emphasis on smoking prevention, curbing the alcohol epidemic, and promoting healthier diets, the health system in Poland would go bankrupt. These positive changes in health behavior, brought about by a strategic approach to health promotion, constructive lobbying, and the effective dissemination of scientific knowledge, led to the most significant reduction in premature mortality in Poland.

\section{STATEMENT BY IWONA SCHYMALLA}

Iwona Schymalla (Fig. 10) recalled that her involvement with the anti-tobacco movement began nearly 20 years ago, when she was a journalist working for Telewizja Polska, the Polish public broadcasting corpora-

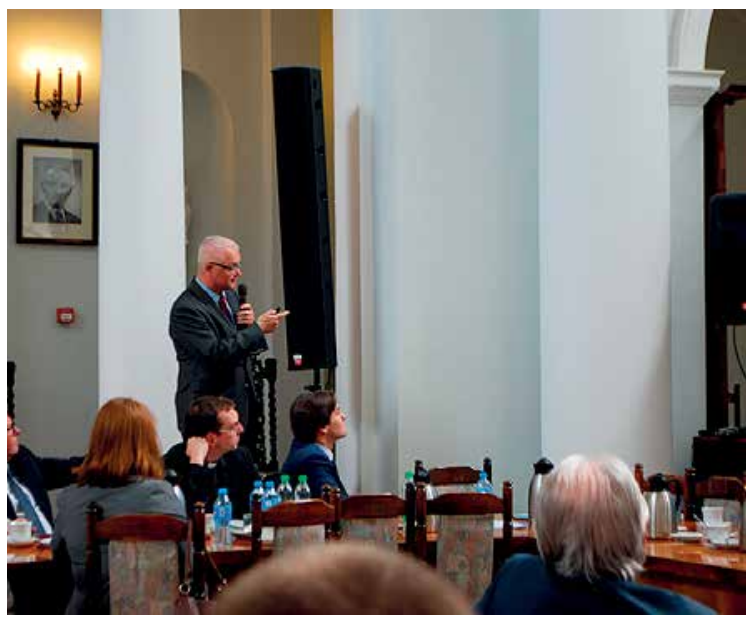

FIG. 9. Professor Tomasz Zdrojewski tion. She was responsible for the coverage of the annual visits to the Vatican of the ex-smokers who participated in the Great Polish-Smoke-out competition. Schymalla remembered the emotions of the people who won a trip to Rome and an audience with the Pope - but also their health. These ex-smokers realised they have done something important for themselves and for their families.

For a journalist interested in health issues, it was particularly important to have the access to, and support of, experts and scientists. They were always willing to participate in the "Kawa czy Herbata" ("Coffee or Tea") morning show, which became a very important element of health education in Poland. Telewizja Polska, through its long engagement in many health promotion programmes, contributed to the change of attitudes towards lifestyle and health in Poland. The thousands of hours of health-related programming, live shows and interviews with experts, contributed to what was probably the only comprehensive and consistent health promotion campaign in Poland. Cigarettes ceased to be perceived as 'cool', and Poles began to quit en masse.

\section{STATEMENT BY ANDRZEJ PĄGOWSKI}

Andrzej Pąowski (Fig. 11), a famous Polish artist and graphic designer, talked about his work on anti-tobacco posters. His most famous work on this topic was the "Papierosy są do dupy" (in free translation - 'Cigarettes are shit') poster (Fig. 12). Pągowski recalled that in the early 1990s, the dominant slogan used to discourage children from smoking was „daddy, mommy, don't smoke next to me!". It seemed trite and unconvincing. When he was asked to produce a poster that would appeal to kids, his wife suggested - "just say that they are shit and let it go". The artist took a picture of his son in a baseball cap and based the poster on this image. The resulting work proved very controversial, especially as it was commissioned with public money. During a Parliamentary committee hearing, Pągowski was told by one of the members of parliament that he is mentally ill. The whole issue was

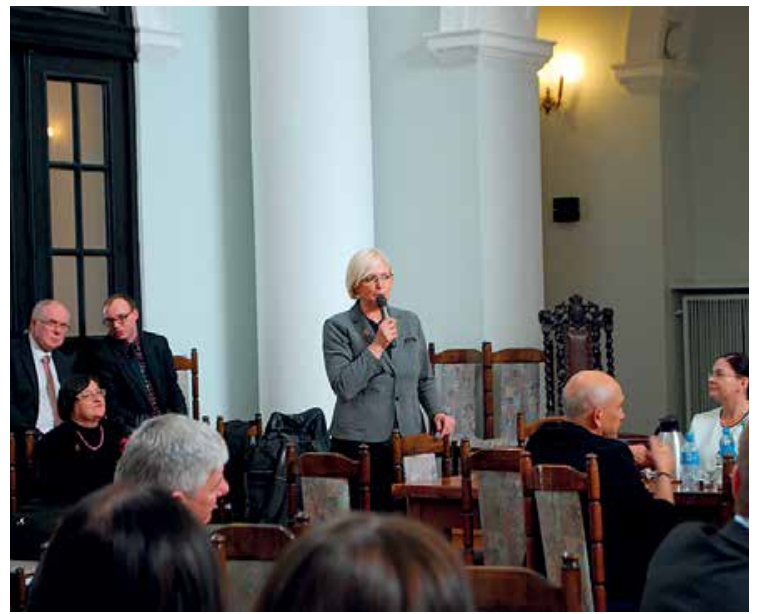

FIG. 10. Iwona Schymalla 


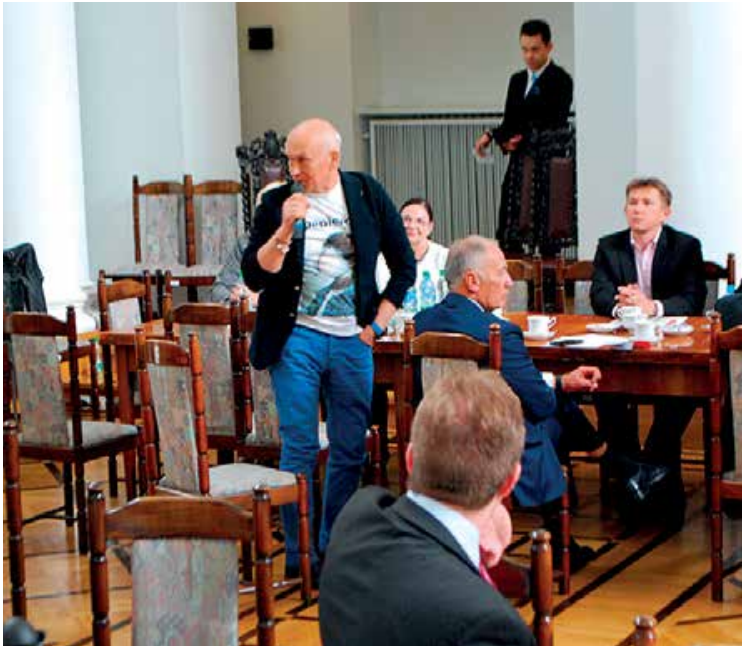

FIG. 11. Andrzej Pągowski

settled thanks to the determination of the Minister of Health, Jacek Żochowski who, in a press conference, said "Ladies and gentlemen, I really don't understand where these emotions come from, we all know deep down that cigarettes are shit, why don't we just finish this debate once and for all?".

\section{STATEMENT BY CARDINAL KAZIMIERZ NYCZ, READ ON HIS BEHALF BY REV. MATTEO CAMPAGNARO}

Cardinal Nycz reminded the audience that the protection of life and care for human health are a central element of the Christian faith. During Pope John Paul II's pontificate, anti-tobacco efforts became a strong part of the theology and social teachings of the Church. This is why the involvement of the Church in anti-tobacco efforts in Poland dates back to the 1980s, when it supported the actions of the Polish Anti-tobacco Society. The leading advocate of this approach was Cardinal Glemp, the Primate of Poland, who himself was personally engaged in the promotion of smoke-free lifestyles, provided spiritual support to persons attempting to quit, and successfully quit himself. Cardinal Glemp was the co-founder and patron of the Health Promotion Foundation, and of the Great Polish Smoke-out. He made sure that the voice of the Church was heard at crucial moments, for instance when the fate of the Polish Anti-Tobacco Law was being decided in Parliament. He was also the driving force behind convincing convincing John Paul II to personally meet every year with a group of ex-smokers who were the winners of the annual Great Polish Smoke-out. This initiative was so popular that in the years 1991-2006 the competition attracted almost half a million participants. Cardinal Glemp also encouraged Catholic institutions to become more involved in anti-tobacco efforts, as evidenced by the work of Professor Urszula Dudziak from the Catholic University of Lublin, Rev. Professor Romuald Jaworski from the Cardinal Stefan Wyszyński University in Warsaw, or Rev. Professor Krzysztof Stępniak.

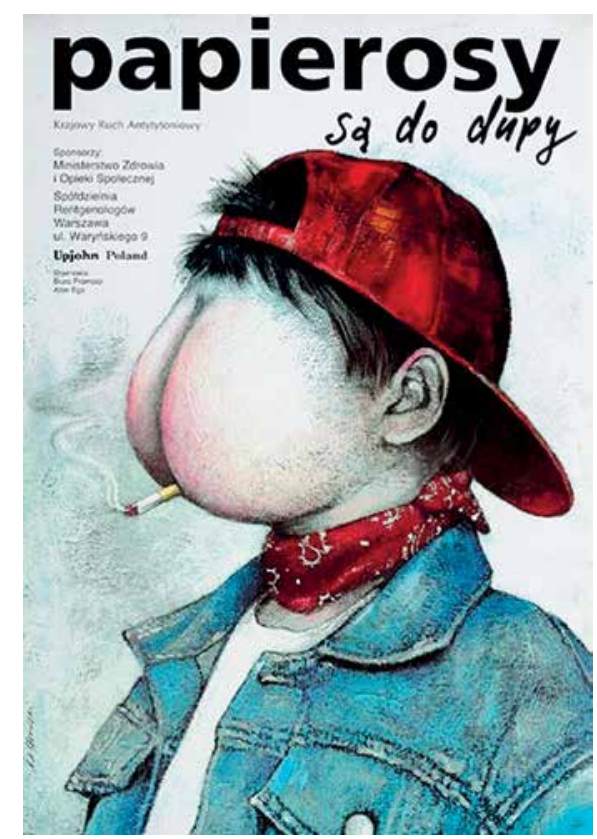

FIG. 12. The controversial poster designed by Andrzej Pągowski - 'Cigarettes are shit'

\section{STATEMENT BY DR ANDRZEJ WOJTYŁA}

In his lecture, the former Minister of Health Andrzej Wojtyła talked about the political context from which the Polish Anti-Tobacco Law arose. In the early 1990s, when he was a member of parliament, it seemed that even simple tobacco control legislation would be extremely difficult to introduce. In 1992, there were efforts in the Senate, led by Senator Adam Struzik, to push forward a strong anti-tobacco bill. However, the tobacco companies used fear tactics effectively, claiming that Polish agriculture will be ruined by anti-tobacco regulations. In a period in which state farms were being restructured and many were going bankrupt, such arguments held sway among policymakers. In this context, Andrzej Wojtyła's attempts to introduce a commitment in the National Health Programme to reduce tobacco consumption by $30 \%$ in respect to 1980 , and to limit the tar content in cigarettes, were uphill struggles. In order to achieve this, countless meetings had to be held to reassure farmers and tobacco planters.

In the later years, the Minister of Health Jacek Żochowski had to be very forceful, also towards members of his own political grouping, in order to achieve the passage of the final version of the Polish Anti-Tobacco Law. Minister Wojtyła was most active in work on an amendment to the Law, which in the late 1990s introduced a ban on tobacco advertising and sponsorship of political parties by the tobacco industry, as well as a provision for $0.5 \%$ of the tobacco excise tax to be spent on tobacco control efforts. The latter provision in practice was observed only for the first few years. In the same amendment, there was also an attempt to ban smoking in cars, but this failed.

The role of the Sanitary Inspectorate was crucial in ensuring the effective enforcement of the Anti-Tobacco 
Law. People like Elżbieta Łata, Joasia Skowron, or the Chief Sanitary Inspector Marek Posobkiewicz, conducted and continue to carry out multiple programmes limiting tobacco use across Poland. It is important for the National Cancer Control Programme to keep aside a pool of funds for anti-tobacco promotion and prevention, as these are a much more effective and cheaper way to improve health indicators than expensive diagnostics or treatment.

Andrzej Wojtyła recalled that initially he did not realise how significant the provisions of the Anti-Tobacco Law were. Only a few years later, at an American Public Health Association meeting, he was made aware by one of the participants that the ban on tobacco advertising was probably one of the most important factors contributing to the improvement of health in Poland. The Polish success in the fight against tobacco was admired in the world.

\section{CONCLUSION BY MINISTER JAROSŁAW PINKAS}

In his closing remarks, Minister Pinkas made the following declaration: "Cigarettes are indeed shit, and I promise that we will not be short on the determination about which Andrzej Pągowski spoke. We will keep going forward, we will succeed, we will be a tobacco-free country".

\section{DISCLOSURE}

Author reports no conflict of interest.

\section{References}

1. Zatoński M, Zatoński WA, Przewoźniak K, et al. The significance and impact of the Polish Anti-Tobacco Law. J Health Inequal 2016; 2: 32-35.

2. Zatoński W. Droga do zdrowia. Historia przeciwdziałania epidemii chorób odtytoniowych w Polsce [The path to health. History of fighting tobacco-related diseases in Poland]. Cancer Centre and Institute, Warsaw 2003.

3. Zatoński M. Evidence-based policy making? The case of Polish opposition to the EU Tobacco Products Directive. J Health Inequal 2016; 2: 36-39.

4. Amendment to the Polish Anti-Tobacco Law introduced on 22 July 2016. Available from: http://dziennikustaw.gov.pl/du/ 2016/ $1331 / 1$

5. Zatoński WA, Zatoński M. Health in the Polish People's Republic. J Health Inequal 2016; 2: 7-16.

6. Zatoński WA, Zatoński M. Democracy is healthier - health in Poland in the late 1980s and 1990s. J Health Inequal 2016; 2: 17-24.

7. Zatoński W, Becker N, Gottesman K, et al. Atlas of cancer mortality in Poland 1975-1979. Springer-Verlag, Berlin 1988. 